\title{
EDUCATIONAL MEASURES ACCORDING TO ALBANIAN PENAL
}

\section{LEGISLATION}

MIRGEN PRENÇE

Lecturer at Faculty of Law

Tirana Business University College

\begin{abstract}
:
The paper analyzes the educational measures in the historical field beginning with the Albanian Criminal Code of 1928 until nowadays. The criteria for providing educational measures under the criminal legislation, as well as the assignment and revocation of educational measures, are analyzed. There are comparable types of educational measures under current criminal legislation to those of previous criminal codes to see what educational measures are appropriate to be put in legislation. Comparative aspects occupy a special place where our legislation will be compared with educational measures with some of Balkan states.
\end{abstract}

Key words: Educational Measures, Legislation, Criminal Law, Prevention, Penalty

\section{Historical Review of Educational Measures}

Educational measures although not specifically, they were grouped in the 1928 Criminal Code. At the request of the prosecutor, the court could decide that the juvenile should be locked up in an institute of education and improvement until he reaches the age of twenty. The court may revoke the closing decision at an institute of education and improvement and decide that the child be handed over to the parents or the person responsible for the education.

The criminal law ${ }^{1}$ provided sanctions when the child was given to their parents or the responsible person for his education. In these cases ${ }^{2}$ the court gave orders to take care for the child, the parents or the responsible person for his education. These people had the obligation to see the behavior of the child. If they did not realize that the kid perform any kind of delinquents, had to pay a fine from one hundred to five hundred gold francs.

The educational measure could be applied when for the committed offense is predicated a sentence of imprisonment, not less than one year.

Almost the same educational measures are also noted in the Criminal Code of 1952. Article 39 of this code provided as educational measures for the juvenile to be handed over the care of the parents, adopters, loved ones and other close relatives, have the opportunity to keep it, people or institutions and lock in a special institution of education and treatment.

\footnotetext{
${ }^{1}$ Article 54 par. 1 Albanin Criminal Code, 1928.

${ }^{2}$ Article 54 par. 2 Albanian Criminal Code, 1928.
} 
The Criminal Code of 1977 in Article 28 provided two educational measures: the placement of a minor in an educational institution and the leniency of the person for education to the collective or social organizations. With the changes in 1988, the following educational measures were added: social reprimand, the impetus for the attestation for one year, the assignment to a job that is paid less in 6 months in the same enterprise, institution and social organization, other social organization or organization within the district, prohibition of exercising a particular activity or skill for a period of one to five years and dismissal. Warning or reprimand by the police may be applied to those children who have committed minor offenses ${ }^{3}$.

Regarding juvenile legislation, states can be classified into two groups. The first group includes those countries that do not have a special law on juveniles in the legislation, but have a special chapter dealing with juvenile affairs in the Criminal Code. Here are parts of countries such as Hungary, Bulgaria, Slovenia, Lithuania, etc.

The second group includes those countries that have a special law on minors in domestic legislation. In this category are: France, Germany, Albania, Germany, Switzerland, Romania, Croatia, Serbia, Macedonia, Kosovo.

The Committee on the Rights of the Child emphasizes the fact that many provisions are left at the discretion of the Member States of the Convention on the Rights of the Child. Discretion is also related to laws and procedures. They may be dealt with in separate chapters in the general part of the Criminal Code and the Criminal Procedure Code or set out in a separate law ${ }^{4}$.

There are countries where no person below the age of 18 is sentenced to imprisonment. These young people are under the auspices of social agencies and are not in countries that are part of the criminal justice system ${ }^{5}$.

For juveniles, detention should be the last measure given and should be applied in special cases $^{6}$.

\footnotetext{
${ }^{3}$ Femi Sufaj, Marinela Sota, Rasim Gjoka, Manual trajtimi per profesionistet qe punojne me femijet ne sistemin penitenciar, INFBOTUES, Tirana, 2012, p. 11.

${ }^{4}$ Committee on the Rights of the Child, General Comment No. 10 "Children's rights in juvenile justice", p. 24. http://www2.ohchr.org/english/bodies/crc/docs/CRC.C.GC.10.pdf

${ }^{5}$ Femi Sufaj, Marinela Sota, Rasim Gjoka, Manual trajtimi per profesionistet qe punojne me femijet ne sistemin penitenciar, INFBOTUES, Tirana, 2012, pp. 13-14.

${ }^{6}$ Femi Sufaj, Marinela Sota, Rasim Gjoka, Manual trajtimi per profesionistet qe punojne me femijet ne sistemin penitenciar, INFBOTUES, Tirana, 2012, p. 14.
} 
States that are part of it, are obliged to take all measures to protect children from entering into conflict with the law. As a result of the lack of juvenile justice policy, the states only provide some statistics on the measures given to children who are in conflict with the law? ${ }^{7}$.

At the moment when an educational or educational measure is taken, the age of the child should be taken into account, reintegrating the child into society and taking a constructive role in society. This principle applies throughout the process of dealing with the child at the time of contact with the law enforcement agencies. It is necessary for the persons involved in the administration of juvenile justice to take into account child development and persistence ${ }^{8}$. In the doctrine was mentioned the idea that:

After the adoption of the Constitution in 1998, several important laws have been passed, which have completed the legal framework of the juvenile justice system, such as Law no. 8328 dated 16.04.1998 "On the rights and treatment of prisoners and detainees", Law no. 8331 dated 21.04.1998 "On the execution of criminal decisions", Law no. 8677 dated 02.11.2000 "On the judicial police", Law no. 8678 dated 14.05.2001 "On the organization and functioning of the Ministry of Justice", Laws on the State Police, the Prison Police, the organization of the judicial power in the Republic of Albania, etc ${ }^{9}$.

All the laws mentioned above play an important role in the juvenile justice system, but it can't be said that the juvenile justice system is complete. The fact that the juvenile justice system is incomplete shows the inclusion of juvenile justice in justice reform.

The establishment of juvenile justice is indispensable, even delayed. This should be integral to the reform in justice, as Albania has a discrepancy between the standards set by the many international children's rights documents, dating back to the past and the projections in the law, between the standards for a friendly juvenile justice foreseen in different laws and degree of recognition and respect for them in practice; the number of children in contact with justice and the forms of reaction of the justice system ${ }^{10}$.

There was a need for a specific law on juvenile justice to offer those who are charged or punished for criminal offenses, but also those who are victims or witnesses of these offenses, protection and treatment that is needed, other than adults ${ }^{11}$.

\footnotetext{
${ }^{7}$ Commitee On The Rights of The Child, Children's rights in juvenile justice, 2007, p. 3. https://www2.ohchr.org/english/bodies/crc/docs/CRC.C.GC.10.pdf

${ }^{8}$ Commitee On The Rights of The Child, Children's rights in juvenile justice, 2007, p. 6. https://www2.ohchr.org/english/bodies/crc/docs/CRC.C.GC.10.pdf

${ }^{9}$ Femi Sufaj, Sistemi i drejtesise per te mitur ne Shqiperi krahasuar me standartet nderkombetare, Revista Shqiptare per Studime Ligjore, nr.1/2011, p. 66.

${ }^{10}$ Part of the speech of Prof. Dr. Vasilika Hysi ne kuader te tryezes se konsultimit publik me teme "Drejtesia e te Miturve ne fokus te Reformes se Sistemit te Drejtesise ne Shqiperi",

http://www.reformanedrejtesi.al/aktivitet/drejtesia-e-te-miturve-ne-fokus-te-konsultimit-publik-per-reformenne-sistemin-e

${ }^{11}$ Part of the speech of Renate Winter, anetare e Komitetit te OKB-se mbi te drejtat e femijes ne kuader te tryezes se konsultimit publik me teme "Drejtesia e te Miturve ne fokus te Reformes se Sistemit te Drejtesise ne Shqiperi",

http://www.reformanedrejtesi.al/aktivitet/drejtesia-e-te-miturve-ne-fokus-te-konsultimit-publik-per-reformen$\underline{\text { ne-sistemin-e }}$
} 
January 1, 2018, Law No. 37/2017 "Law on Juvenile Justice" entered into force. Albanian lawmaker made steps in advance to protect the juvenile, providing for special rates for minors who commit criminal offenses.

From previous studies it has been noted that there were no specific services for children under the age of criminal responsibility, under 14 years of Albanian criminal legislation and who commit criminal offenses ${ }^{12}$.

These specific services were created by the Law 18/2017 on the Rights and Protection of the Child, by the Council of Ministers Decision no. 635 date. 26.10 .2018 for the activity of child protection structures, regarding the underage child for criminal responsibility, who is suspected or committed a criminal offense.

\section{Implementation of educational measures}

The Albanian lawmaker had erroneously provided for a provision as medical and educational measures without defining what was meant by them, but this matter was regulated by the entry into force of Law no. 36/2017 amending Article 46 of the Criminal Code and for educational measures refers to the Juvenile Justice Code.

Article 46 of the Criminal Code refers to the Juvenile Justice Code for the application of educational measures, but the Juvenile Justice Code in Article 4 provided in this Code do not include juveniles who commit criminal offenses under the age of accountability criminal. This category of minors has been excluded from the application of the Juvenile Justice Code.

Law 18/2017 on the Rights and Protection of Children has provided for protection units for children who commit criminal offenses and are under the age of 14 (excluded from criminal liability), child protection workers in the administrative unit of the municipality ${ }^{13}$. According to Article 55, paragraph 2, letter dh) of Law 18/2017 On the rights and protection of the child protective measures are imposed on a minor who has committed a criminal offense and, because of his age, has no criminal responsibility;

Law 18/2017 On the Rights and Protection of Children in its Article 66 provides for specialized oversight measures for under-age children for criminal responsibility such as:

a)going to school on a regular basis;

b)participation in activities of pre-service services;

c) the pursuit of medical treatment or psychological counseling;

\footnotetext{
${ }^{12}$ Aida Bushati, Geron Kamberi, Florian Xhafa, Holta Ymeri, Mona Xhexhaj, Nirvana Deliu, Sajmira Kopani, Konventa per integrim europian. Vleresime dhe rekomandime 2015-2016. Levizja Europiane ne Shqiperi, FLESH, Tirane, 2016, p. 28

${ }^{13}$ Article 50 of Law 18/2017 Per te Drejtat dhe mbrojtjen e femijes.
} 
ç) Prohibitions to go or attend certain places.

In the case of a minor who has no criminal responsibility because of age, it is necessary to place a minor under a rigorous control regime to prevent his behavior with damaging consequences for society ${ }^{14}$.

Educational measures can be classified into two categories:

a) Educational measures that apply under the Juvenile Justice Code when persons have criminal responsibility.

b) Educational measures that apply under Law 18/2017 on Rights and Child Protection for Children Exempt from Criminal Responsibility because they have committed a criminal offense when they have been under the age provided by law to have criminal responsibility. The court is not obliged to provide an educational measure, but has the freedom to impose a sanction or educational measure. As provided by the provision, they are provided only by the court and not by another institution such as the prosecution or the police.

Article 55 of the Juvenile Justice Code provides for the conditions of avoiding prosecution when it comes to criminal offenses foreseeing a sentence of up to 5 years and when the other conditions provided for in the law are met, the prosecutor or the court may introduce educational measures for the minor.

The categories of people who are taken educational measures are: to children under the age of 14 who have no criminal responsibility and to children over 14 years in case they exclude from criminal liability (in the case of commission of the criminal offense the court did not appeal imprisonment but applies an educational measure).

The penal code does not provide for the minimum age when such a measure may be applied, whereas in relation to the age of the maximum application of this measure it is defined indirectly because it applies to minors, e.g people up to 18 years.

The educational measure of placement of a minor in an educational institution is irrevocable at any time when the circumstances for which this measure is abolished. The court has the legal obligation to review its decision from the moment one year has elapsed from the day of its decision.

The court must be careful when applying a measure restricting the freedom of the person such as imprisonment. When the court apply an educational measure and another restricting freedom should take into account the best interest of the child, the right to enjoy a better health status

\footnotetext{
${ }^{14}$ Shefqet Muçi, E drejta penale. Pjesa e pergjithshme. Albdesign, Tirane, 2017, p. 305.
} 
and to benefit from the treatment of illness and health rehabilitation, the development of the personality, the gifts, the mental, social and physical abilities of the child.

Having the obligation deriving from the Convention on the Rights of the Child to take all legislative, administrative, social and educational measures to protect children from various forms of violence, ill-treatment, exploitation or sexual abuse, the court must apply a measure educational and, in exceptional cases, a measure that limits the freedom of the person ${ }^{15}$. In most cases, juveniles commit minor offenses and in many European countries these issues are resolved quickly and a sanction is imposed on juveniles, while in Albania it happens because such processes last for years and do not serve the minor's rehabilitation to be integrated as soon as possible in the society ${ }^{16}$.

\section{Comparative Review of Educational Measures}

\section{Kosovo:}

Educational measures in Kosovo are provided in the Juvenile Justice Code. Article 20 of this code classifies educational measures that are assigned to minors in three categories:

1) mass-disciplinary;

2) added surveillance measures;

3) institutional measures.

Disciplinary measures include: judicial reprimand and send juvenile to a disciplinary center. These measures are assigned to a minor offender when the offense is committed by negligence. Additional surveillance measures presuppose increased supervision by the parent, adoptive parent, guardian or guardianship body. These measures are imposed on juveniles whose interests do not require isolation from their previous environment and are implemented in a long-term manner that the juvenile offers the opportunity for education, rehabilitation or treatment. The duration of this measure may not be less than three (3) months or longer than two (2) years.

Educational institutional measures are: send the juvenile to an educational institution, to a Correctional Education Institution or to the Special Care Institution. These measures are imposed on juveniles whose interests best suit their segregation from the previous and longterm environment, providing the minor with the opportunity of education, rehabilitation or treatment.

\footnotetext{
${ }^{15}$ Article 19 of Convention on the Rights of the Child.

${ }^{16}$ Etilda Saliu, Masat e sigurimit personal per te miturit si autore te vepres penale, Avokatia, no. 14/2015, p.59.
} 
The lawyer has also established a general condition for all types of educational measures that have to do with not exceeding the maximum term of imprisonment foreseen for the criminal offense.

The duration of the educational measure may not exceed the maximum term of imprisonment foreseen for the criminal offense. Article 21 of the Juvenile Justice Code sets out the rules for the implementation of various educational measures.

\section{Macedonia}

Educational measures in Macedonia are almost the same as those of the Republic of Kosovo. Article 31 of the Law on the Rights of the Child provides for these educational measures:

1) Reprimand or dispatch to the Disciplinary Center for Minors;

2) Supervision by the parent, guardian, or dependent family;

3) Entity measures: instruction in the educational institution or correctional educational home. The following Article 34 provides for the conditions for the implementation of various measures.

In the case of children committing criminal offenses, there is a kind of tension between education and punishment. This is also noticed in the legal reforms that took place in Germany in 1990, in the Netherlands in 1995, in Spain in 2000 and 2006, in Portugal in 2001, in France and in Northern Ireland in 2002, in Lithuania in 2001 in Czech Republic in $2003^{17}$.

In England, educational and disciplinary measures applied to children range from 10 to 18 years old age.

\section{Recommendations of the Council of Europe}

Responding to juvenile offenders should be multifaceted several factors that need to be taken into account: the individual, the family, the school, and the community ${ }^{18}$.

When a minor commits a criminal offense, the main purpose at the moment when an educational measure is awarded, is to prevent the commission of criminal offenses, their reintegration ${ }^{19}$.

It is necessary that the legal norms to deal with educational measures should also apply to people who are young adults and have reached the age of 18. The purpose of applying adult

\footnotetext{
${ }^{17}$ Frieder Dünkel, Juvenile Justice Systems in Europe-Reform developments between justice, welfare and 'new punitiveness', Kriminologijos Studijos, no.1/2014, p. 35.

${ }^{18}$ Recommendation Rec (2003) 20 of the Committee of Ministers to member States concerning new ways of dealing with juvenile delinquency and the role of juvenile justice.

${ }^{19}$ Recommendation Rec (2003) 20 of the Committee of Ministers to member States concerning new ways of dealing with juvenile delinquency and the role of juvenile justice.
} 
education to adults is that this category is moving from childhood to adulthood, is in a kind of transition. It should be emphasized the fact that there are a number of acts of international character that support the application of rules that are related to the minor to the young adult. For example The Convention on the Protection of the Rights of the Child, Rule 3.3 of the Rules of the Beyizhin, Article 17 of Council of Europe Recommendation CM / Rec (2008) 11 on sanctions and measures applied to young authors.

Recommendation CM / Rec (2008) 11 of the Council of Europe on sanctions and measures applied to new authors does not expressly provide for the types of sanctions or educational measures that apply to juveniles, but sets out some criteria to support states.

The recommendation in point 24 provides that states should envisage in domestic legislation: a) the definition and manner of applying the sanction and the measures applicable to juveniles;

b) any condition or obligation that is the consequence of such an offense or measure; c) cases where it is necessary to approve the juvenile before the application of the sanction or measure;

d) Institution responsible for establishing, amending and enforcing sanctions or measures;

e) procedures related to the change of sanction or measure;

f) Procedures for the regular and external monitoring of the implementing institution.

\section{Conclusions:}

In order to avoid ambiguity and make it easier to implement and understand educational measures, the Albanian lawmaker should amend Article 46 of the Albanian Criminal Code, where the referral should not refer only to the Juvenile Justice Code but also to the special law dealing with educational measures for juveniles who commit criminal offenses but are excluded from criminal liability.

From the analysis of Albanian legislation and that of Macedonia and Kosovo we noticed that the changes are not very large because the Juvenile Justice Code has been adapted to the juvenile crime legislation with European states.

\section{Bibliography:}

Aida Bushati, Geron Kamberi, Florian Xhafa, Holta Ymeri, Mona Xhexhaj, Nirvana Deliu, Sajmira Kopani, Konventa per integrim europian. Vleresime dhe rekomandime 20152016. Levizja Europiane ne Shqiperi, Flesh, Tirane, 2016.

Etilda Saliu, Masat e sigurimit personal per te miturit si autore te vepres penale, Avokatia, no. $14 / 2015$. 
Femi Sufaj, Marinela Sota, Rasim Gjoka, Manual trajtimi per profesionistet qe punojne me femijet ne sistemin penitenciar, INFBOTUES, Tirana, 2012.

Femi Sufaj, Sistemi i drejtesise per te mitur ne Shqiperi krahasuar me standartet nderkombetare , Revista Shqiptare per Studime Ligjore, nr.1/2011.

Frieder Dünkel, Juvenile Justice Systems in Europe-Reform developments between justice, welfare and 'new punitiveness', Kriminologijos Studijos, no.1/2014.

Shefqet Muçi, E drejta penale. Pjesa e pergjithshme. Albdesign, Tirane, 2017.

Committee on the Rights of the Child, General Comment No. 10 "Children's rights in juvenile justice". http://www2.ohchr.org/english/bodies/crc/docs/CRC.C.GC.10.pdf

Part of the speech of Prof. Dr. Vasilika Hysi ne kuader te tryezes se konsultimit publik me teme "Drejtesia e te Miturve ne fokus te Reformes se Sistemit te Drejtesise ne Shqiperi", http://www.reformanedrejtesi.al/aktivitet/drejtesia-e-te-miturve-ne-fokus-te-konsultimitpublik-per-reformen-ne-sistemin-e

Part of the speech of Renate Winter, anetare e Komitetit te OKB-se mbi te drejtat e femijes ne kuader te tryezes se konsultimit publik me teme "Drejtesia e te Miturve ne fokus te Reformes se Sistemit te Drejtesise ne Shqiperi”,

http://www.reformanedrejtesi.al/aktivitet/drejtesia-e-te-miturve-ne-fokus-te-konsultimitpublik-per-reformen-ne-sistemin-e

Recommendation Rec (2003) 20 of the Committee of Ministers to member States concerning new ways of dealing with juvenile delinquency and the role of juvenile justice.

Albanin Criminal Code, 1928.

Law 18/2017, Per te Drejtat dhe mbrojtjen e femijes. 